\title{
Osmotic adjustment in sessile oak seedlings in response to drought
}

\author{
C Collet $^{1^{*}}$, JM Guehl $^{2}$ \\ 'Équipe croissance et production ; \\ ${ }^{2}$ Équipe bioclimatologie et écophysiologie, Unité écophysiologie forestière, \\ Inra Nancy, 54280 Champenoux, France
}

(Received 22 August 1996; accepted 10 December 1996)

\begin{abstract}
Summary - Three-year-old sessile oak seedlings were submitted to drought developed at two different rates $\left(0.050\right.$ and $\left.0.013 \mathrm{MPa} \mathrm{day}^{-1}\right)$. Drought was controlled by combining levels of irrigation and grass competition. At the end of summer, predawn leaf water potential reached values of -2.3 and $-0.8 \mathrm{MPa}$ in the rapid and slow rates of drought development, respectively, and leaf osmotic potential at full turgor reached values of -2.0 and $-1.5 \mathrm{MPa}$, for the same treatments. For both treatments, leaf water potential and leaf osmotic potential were linearly and positively correlated. The rapid rate of drought development resulted in a greater degree of osmotic adjustment $\left(0.45\right.$ versus $\left.0.34 \mathrm{MPa} \cdot \mathrm{MPa}^{-1}\right)$.
\end{abstract}

\section{Quercus petraea / water deficit / osmoregulation}

Résumé - Effets d'une sécheresse édaphique sur l'ajustement osmotique de jeunes plants de chêne. Des plants de chêne sessile âgés de 3 ans ont été soumis à des déficits hydriques se développant à deux vitesses $\left(0,050\right.$ et $0,013 \mathrm{MPa} \cdot$ jour $\left.^{-1}\right)$, obtenus en croisant deux niveaux d'irrigation et de compétition herbacée. À la fin de l'été, le potentiel hydrique foliaire de base était de $-2,3$ et - 0,8 MPa sous dessèchement rapide et sous dessèchement lent, respectivement. Le potentiel osmotique foliaire à pleine turgescence était de $-2,0$ et - 1,5 MPa dans les mêmes traitements. Dans les deux traitements, le potentiel hydrique de base et le potentiel osmotique étaient linéairement et positivement corrélés. Le dessèchement rapide a induit un degré d ajustement osmotique plus important $\left(0,45\right.$ contre $0,34 \mathrm{MPa} \cdot \mathrm{MPa}^{-1}$ sous dessèchement lent).

Quercus petraea / déficit hydrique/ osmorégulation

* Correspondence and reprints

Tel: (33) 0383394043 ; fax: (33) 0383394069 


\section{INTRODUCTION}

Active osmotic adjustment, which refers to the lowering of osmotic potential arising from the net accumulation of solutes, is considered to be one of the important mechanisms by which plants respond to water deficit. The lowering of osmotic potential as plant water potential progressively decreases maintains turgor pressure, which in turn enables the maintenance of cell growth and functional integrity (Turner and Jones, 1980; Morgan, 1984).

The ability of sessile oak (Quercus petraea Liebl) seedlings to osmotically adjust in response to water deficit has been shown by Osonubi and Davies (1978), Vivin et al (1996) and Epron and Dreyer (1996). However, these observations were made on oak seedlings grown in pots, where the restricted rooting volume induced a rapid rate of water deficit development. Under natural conditions, slower rates of drought development generally occur (Ravier, 1989; Epron and Dreyer, 1993), and since the rate of drought development influences the degree of osmotic adjustment (Jones and Rawson, 1979; Turner and Jones, 1980), pot studies may have underestimated the capacity of the seedlings to osmotically adjust.

The objective of this study was to quantify the degree of active osmotic adjustment for sessile oak seedlings in response to a drought developing at rates similar to those observed in natural conditions. and to investigate if the rate of soil drying influences the degree of osmotic adjustment. Oak seedlings planted in semi-controlled conditions were subjected to summer-like drought regimes. Two soil water regimes were used: one simulating a very slow rate using bare soil, the other mimicking the conditions of a seedling in a competitive situation. Conditions of competitive soil water extraction (White et al, 1992) were created by growing the oak seedlings in a mixture with grass (Deschampsia cespitosa L).

\section{MATERIALS AND METHODS}

The experimental design, set up at the Inra center of Nancy (France) consisted of 40 boxes built under a plastic roof that eliminated natural precipitation. The boxes $(2 \mathrm{~m}$ long $\times 2 \mathrm{~m}$ wide $\times$ $0.5 \mathrm{~m}$ high) were filled with a sandy-loam soil. In June 1991, five 1-year-old sessile oak seedlings from a natural forest regeneration in northeastern France were transplanted into each box. The seedlings were grown for 3 years under different moisture regimes obtained by combining levels of irrigation and grass competition. In June 1991, 20 boxes were sown with Deschampsia, and the remaining 20 boxes were kept without grass. For 3 years, the grass sward and the bare soil were maintained by manual weeding. In 1991, all the boxes were watcred to field capacity so the plants could establish. In 1992 and 1993, half of the boxes were maintained near field capacity by regular irrigation during the whole growing season. The other half was first maintained near field capacity and then submitted to drought by withholding water during July and August. After August, they were again irrigated except in 1993 for those in bare soil. In 1993, the bare soil boxes were not watered until October. A detailed account of the experimental design and the timecourse of soil water availability may be found in Collet et al (1996). The four specific regimes of the oak seedlings were: BI, bare soil and irrigation (no drought): BS, bare soil and no irrigation (slow rate of drought development); GI, gralss competition and irrigation (no drought): and GS, grass competition and no irrigation (rapid rate of drought development).

Seedling predawn leaf water potential $\left(\Psi_{w}\right.$, MPa) was measured with a pressure chamber (PMS Inc, Corvallis, OR, USA) each year between June and September. At each measurement date, four to eight boxes were selected from each treatment. Measurements were made on one randomly chosen seedling from cach selected box. Measurements of leaf osmotic potential at full turgor $\left(\Pi_{0}, \mathrm{MPa}\right)$ were made on the same dates as $\Psi_{w}$ measurements, every week in 1992 and only five times at the critical periods in 1993 (before, during, and after the drought). After $\Psi^{\prime}$ was determined, the leaf was carefully washed and was floated on water for $4 \mathrm{~h}$ until it resaturated. The leaf without the midrib was then put into a syringe and plunged into liquid nitrogen. Ten microliters of sap were extracted and used to determine $\Pi$ with a vapor pressure osmometer (model 550, Wescor Inc, Logan, UT. USA). Lin- 
ear regressions (SAS Institute Inc, 1989) were used to analyze the relationships between predawn $\Psi_{w}$ and $\Pi_{i}$, and differences between regression lines were evaluated with a general linear test (Neter et al, 1990).

\section{RESULTS AND DISCUSSION}

The time-course of predawn water potential and osmotic potential at full turgor in the seedlings is shown in figure 1 . The timecourse of predawn $\Psi_{w}$ was similar to levels measured by Ravier (1989) on young oak seedlings grown under natural conditions in competition with Deschampsia or in bare soil. In both summers, predawn $\Psi_{w}$ in the irrigated treatments stayed around $-0.2 \mathrm{MPa}$ and $\Pi_{\mathrm{o}}$ around $-1.3 \mathrm{MPa}$. No statistically significant seasonal variation in $\Pi_{\mathrm{o}}$ was observed, indicating an absence of seasonal trend owing to factors such as leaf aging or climatic conditions. In treatment GS, seedlings experienced severe drought from the end of July to mid-August in both years and, as soil water deficits increased, seedlings exhibited strong osmotic adjustment. Individual predawn $\Psi_{w}$ values ranged between 0 and $-3.30 \mathrm{MPa}$ in 1992 and between 0 and $-3.80 \mathrm{MPa}$ in 1993, while individual $\Pi_{0}$ values ranged between -1.05 and -2.24 MPa in 1992 and between -0.90 and -2.15 MPa in 1993 (fig 2). In both years,

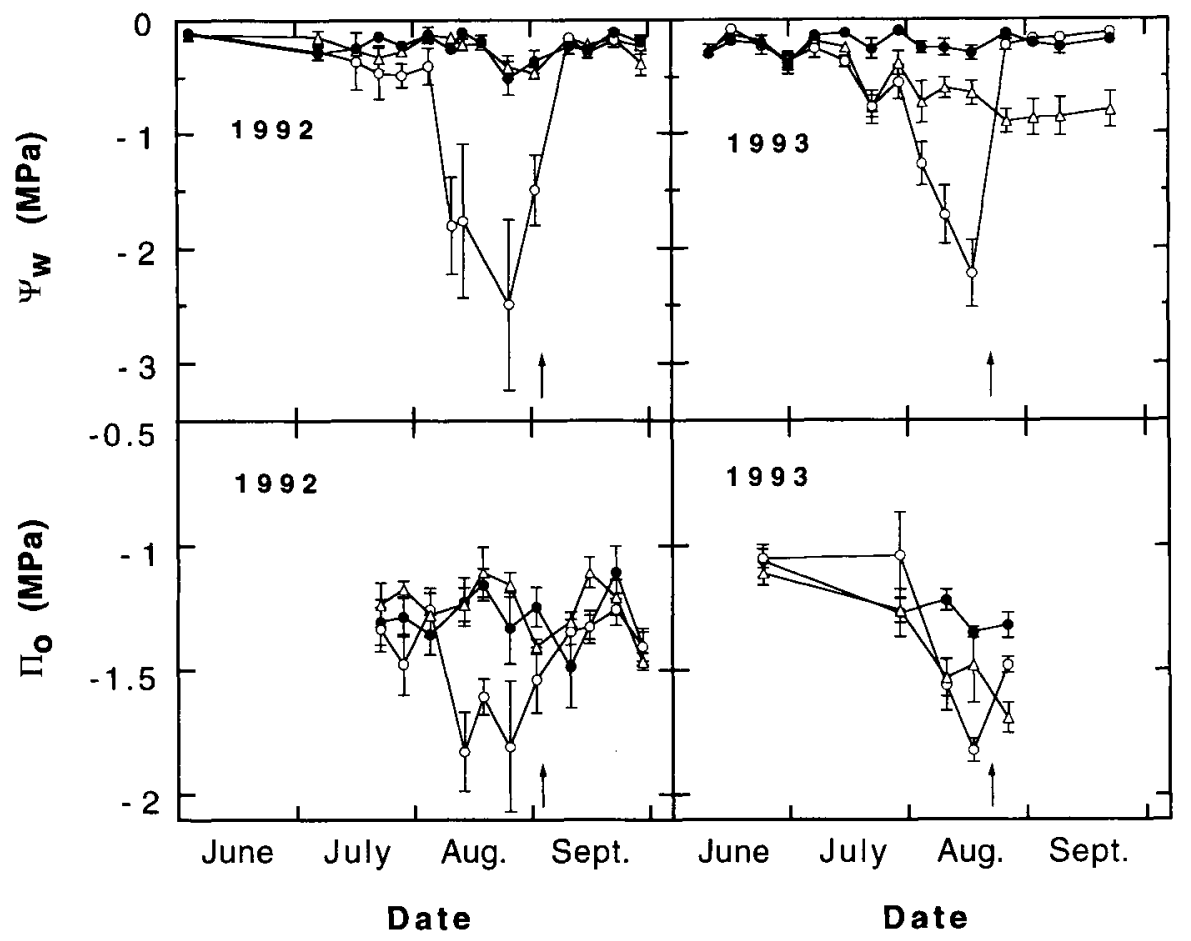

Fig 1. Time-course of predawn leaf water potential $\left(\Psi_{\psi}\right)$ and leaf osmotic potential at full turgor $\left(\Pi_{0}\right)$ measured on oak seedlings grown under combined levels of irrigation (I: irrigated; S: waterstressed) and grass competition (B: bare soil; G: grass competition) during the summers of 1992 and 1993 (mean $\pm \mathrm{SE}, n=4-10)$. The arrow indicates the rewatering in treatment GS. 
predawn $\Psi_{w}$ and $\Pi_{0}$ were linearly and positively correlated (table I). For the BS treatment, drought was insufficient in 1992 to induce any change in $\Pi_{0}$. However, in 1993, predawn $\Psi_{\mathrm{w}}$ and $\Pi_{\mathrm{o}}$ decreased slowly during summer, and at the end of summer, $\Pi_{0}$ values ranged between -1.7 and $-2.0 \mathrm{MPa}$.

The return of $\Pi_{\mathrm{o}}$ to predrought values in the water-stressed seedlings after rewatering was not immediate. In 1993, measurements of $\Pi_{\mathrm{o}}$ were made 8 days after the rewatering, and $\prod_{0}$ values were significantly lower than
$\Pi_{\mathrm{o}}$ values in the irrigated seedlings (fig 2 ). In contrast, in 1992, measurements of $\Pi_{0}$ were made 15 days after the rewatering, and $\Pi_{0}$ values in the water-stressed treatments were similar to those in the irrigated treatments. The full recovery of osmotic potential after rewatering in 1992 suggests that there will be no benefit through an increase in solute content for subsequent periods of water deficit. Similar results were found by Santakumari and Berkowitz (1991) in spinach and by Jones and Rawson (1979)

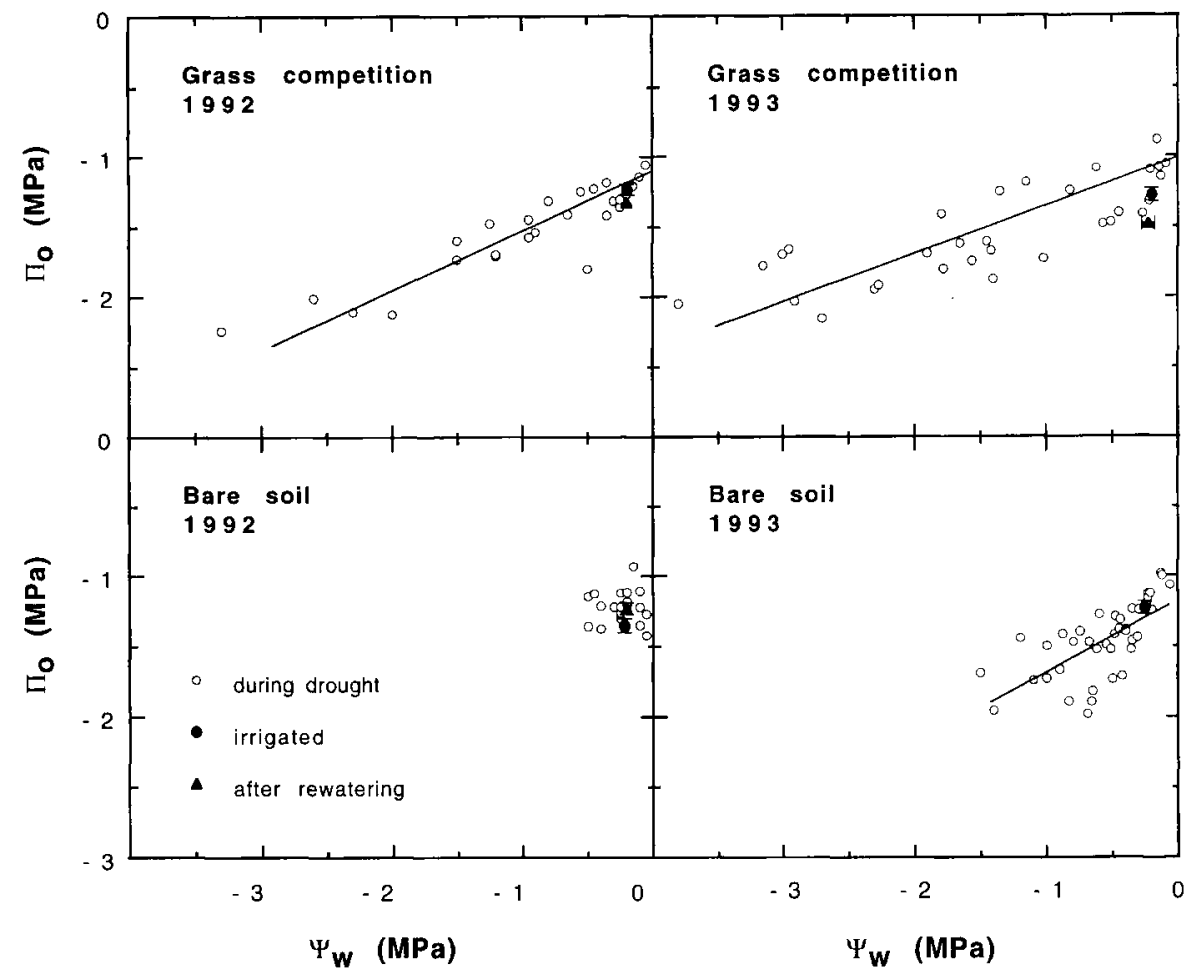

Fig 2. Relationship between leaf osmotic potential at full turgor $\left(\Pi_{i}\right)$ and predawn leaf water potential $\left(\Psi_{w}\right)$ measured for oak seedlings during the summers of 1992 and 1993. Measurements were made on the seedlings grown under bare soil or with grass competition, in the water-stressed treatments during the drought period. Each point represents a couple of measurements made on the same leaf. Regression lines between $\Pi_{0}$ and predawn $\Psi_{u}$ are shown. Values of $\Pi_{0}$ and predawn $\Psi_{w}$ in the irrigated treatments avcraged over the whole measurement period and valucs in the water-stressed treatments alter the rewatering are also shown (mean $\pm \mathrm{SE}, n=12-32$ ). 
Table I. Linear regression analysis, using the equation $\Pi_{0}=a+b \Psi_{w}$, where $\Pi_{0}$ is the leaf osmostic potential at full turgor and $\Psi_{w}$ is the prediwn leaf water potential measured in 1992 and 1993 on sessile oak seedlings grown with (GS) or without (BS) grass competition, and without irrigation.

\begin{tabular}{|c|c|c|c|c|c|c|}
\hline Year & Treatment & $a$ & $b$ & $a d j-\mathbf{r}^{2}$ & $d f$ & $\mathrm{P}>\mathrm{F}$ \\
\hline 92 & GS & -1.19 & 0.35 & 0.81 & 27 & 0.0001 \\
\hline 92 & BS & -1.20 & $0.0 \mathrm{I}$ & 0.06 & 18 & 0.96 \\
\hline 93 & GS & -1.17 & 0.32 & 0.71 & 29 & 0.0001 \\
\hline 93 & BS & -1.19 & 0.45 & 0.39 & 40 & 0.001 \\
\hline \multirow[t]{2}{*}{$92+93$} & GS & -1.19 & 0.34 & 0.67 & 57 & 0.0001 \\
\hline & \multicolumn{4}{|c|}{ Comparison 92 GS - 93 GS: $F=0.59 \mathrm{~ns}$} & & \\
\hline 93 & GS+BS & -1.26 & 0.24 & 0.47 & 70 & 0.0001 \\
\hline
\end{tabular}

For each treatment comparison, results of the $F$-test are indicated. ns: not significant; ${ }^{*} P<0.001$; df: degrees of freedom.

in sorghum, who observed no effect of prior exposure to drought on the extent of osmotic adjustment in response to subsequent water deficit.

Osmotic adjustments shown in the droughted seedlings in this study were greater in magnitude than those found in other studies (Osonubi and Davies, 1978; Vivin et al, 1996) that had been conducted on oak seedlings subjected to a rapid drought (between 0.1 and $0.15 \mathrm{MPa} \cdot \mathrm{day}^{-1}$ ). In our experiment. the rate of development of water deficit was much slower in both treatments. The average rate of drying in treatment GS was similar in both 1992 and $1993(0.048$ and $0.052 \mathrm{MPa} \cdot \mathrm{day}^{-1}$, respectively), and the relationship between predawn $\Psi_{w}$ and $\Pi_{0}$ was also similar in both years. The regression lines obtained in both years did nol differ significantly (table I), indicating a similar degree of osmotic adjustment (about $0.34 \mathrm{MPa} \cdot \mathrm{MPa}^{-1}$ ). Seedlings in treatment BS, which were subjected in 1993 to a drought developing at a slower rate $\left(0.013 \mathrm{MPa} \cdot \mathrm{d}^{-1}\right)$, showed greater osmotic adjustment $\left(0.45 \mathrm{MPa} \cdot \mathrm{MPa}^{-1}\right)$. The relationships obtained in 1993 for the seedlings in treatments GS and BS were significantly different. Our results suggest that a slower development of drought may induce a greater osmotic adjustment, and that oak seedlings in natural conditions may show stronger osmotic adjustment than seedlings grown under controlled conditions and submitted to a rapid rate of drought development (Osonubi and Davies, 1978; Vivin et al, 1996).

\section{REFERENCES}

Collet C. Cikhl JM. Frochot H, Ferhi A (1996) Effect of two forest grasses dittering in their growth dynamics on the water relations and the growth of Quercuss petraea seedlings. Can J Bot 74. 15621.571

Epron D. Jreyer E ( 1993) Compared effects of drought on photosynthesis of adult oak trees (Quercus petraed (Malt) Licbl and Quereds robur L) in a nalural stand. Now Phytol 125, 381-389

Epron D. Dreyer E (1996) Starch and soluble carbohydrates in leaves of water-stressed oak saplings. Alln Sif For 53, 263-268 
Jones MM, Rawson HM (1979) Influence of rate of development of leaf water deficits upon photosynthesis, leaf conductance, water use efficiency, and osmotic potential in sorghum. Physiol Planta 45, 103-111

Morgan JM (1984) Osmoregulation and water stress in higher plants. Ann Rev Plant Physiol 35, 299 319

Neter J, Wasserman W, Kutner MH (1990) Applied Linear Models, 3rd edn. Irwin Inc, Burr Ridye. IL, USA

Osonubi O. Davies WJ (1978) Solute accumulation in leaves and roots of woody plants subjected to water stress. Oecologia 32, 323-332

Ravier A (1989) Intluence de la végétation accompagnatrice forcstière sur le développement de jeunes chênes pédonculés (Quercus pedunculata Ehrh): modifications des paramètres hydriques. Mémoire de DEA, Université de Nancy I, France
Santakumari M, Berkowitz GA (1991) Chloroplast volume: cell water potential relationships and acclimatation of photosynthesis to leaf water deficit. Photosynth Res 28, 9-20

SAS Institute Inc (1989) SAS/STAT User's Guide. Version 6, 4th edn. SAS Institute Inc, Cary, NC, USA

Turner NC. Jones MM (1980) Turgor maintenance by osmotic adjustment: a review and evaluation. In: Adaplation of Plants to Water Stress (NC Turner. PJ Kramer, cds), John Wilcy \& Sons, London, UK, 87-103

Vivin P. Guehl JM. Clément A. Aussenac G (1996) The effects of elevated $\mathrm{CO}_{2}$ and water stress on whole plant $\mathrm{CO}_{2}$ exchange, carbon allocation, and osmoregulation in oak seedlings. Ann Sci For 53, 447-459

White RH, Engelke MC, Morton SJ, Ruemmele BA (1992) Competitive turgor maintenance in tall fescue. Crop Sci 32, 251-256 